\title{
Salting Newborns, the Skin Barrier from Antiquity to Today
}

Eugene L. Mahmoud, MD

Although salting of newborns has been a practice claimed to be part of indigenous culture from antiquity up to the present day, it is a practice not well understood. The purpose of this article is to look at the existing evidence for the use of salting newborns down through time in order to help us understand how this agent and other agents are used to protect the newborn skin against foreign agents and damage after birth.

It is apparent from ancient times that the health of newborns was closely connected to the ability of the skin barrier to protect from objects and agents of illness. Midwives and elderly female relatives helped transmit the benefits believed in salting babies, which included protection from putrefaction, hygiene, morals, warding off evils, preventing a bad smell, and preventing sweating. The Bible in the Book of Ezekiel (King James Version) Chapter 16 Verse 4 portrays the use of salting newborns at birth as a metaphor that compares Jerusalem to an abandoned child:

"And as for thy nativity, in the day thou wast born thy navel was not cut, neither wast thou washed in water to supple thee; thou wast not salted at all, nor swaddled at all".

Dioscorides, Galen, and Soranus of Ephesus are three great physicians from the Greco-Roman Era of Medicine who were aware of the cleansing properties of salt. Dioscorides (40 - 90 A.D.) wrote an encyclopedia, Materia Medica, that was used for centuries after his death. During this time in the care of the newborn, regimens for the care of newborns, as well as older children, were included in the medical texts of Gynecology. While Galen recommended that newborns be treated almost like hams being cured to harden the skin, Soranus cautioned against salt entering the eyes or mouth, as it may produce ulceration, severe inflammation, or suffocation. And much salt should not be besprinkled, for by too great pungency the physique, which is still tender and very weak, is corroded, nor with little, since the surface is not rendered sufficiently firm.

\section{"The rise of the Islamic Civilization in the Middle Ages produced many outstanding physicians, who were influenced by the medicine of Galen and Soranus."}

The rise of the Islamic Civilization in the Middle Ages produced many outstanding physicians, who were influenced by the medicine of Galen and Soranus. The Three Outstanding Physicians known during the Islamic Civilization were Aboo Bakr Muhammad ibn Zakariyyah al-Razi (Rhazes) (865-925), 'Ali ibn al-'Abbas alMajusi (Haly Abbas) (d. 994), and Abu 'Ali al-Husayn ibn 'Abd Allah ibn Sīnā (Aviceena) (980-1037).

In his medical textbook, 'Al Mansour,' dedicated to a prince, Al Rhazes, speaks of neonatal care without explicitly stating the sub- stances with which the newborn should be sprinkled or anointed. The baby's ears should be sucked as he is being born and after. Beware that the milk does not enter [the ears] during nursing. The newborn's palate must be rubbed with honey, and it is necessary to clean his nose by rubbing it with hot water and oil and wiping it. You must also rub and anoint him, stretch out his members in [the appropriate] directions, swaddle him and settle the parts of his head, the forehead, and nose. With these cares, the child is protected against a large number of diseases. And Al Majusi, in his book, 'The Complete Art of Medicine,' on 'The Regimen of the Baby's Bodies', in Chapter 20 of Volume Two, Article One, starts by mentioning:

'However, when a child is born, it should be sprinkled on him with powdered salt and roses reduced to strengthen the skin by it against the air'.

He then goes on to mention other substances applied to the body and the washing of the baby. Whereas, Avicenna who was by far the most prestigious source in Arabo-Islamic medicine and the well-known Arabic physician in Europe, his book, 'The Canon of Medicine' says on Childbirth and the Care of the Skin:

'The face and the body of the newborn should be bathed in saltwater to harden the skin and set the features. The best salt for this purpose is the One, which contains a small quantity of seeds of Indian hemp, costus root, fumitory, fenugreek, and origanum. The saline bath could be safely repeated if the body is found to be still dry or covered with secretions.'

\section{"It is the story of contact and cultural exchange across countries and creeds, affecting caliphs, kings, courtiers, courtesans, and the common crowd. In addition to being fascinating in its own right, medieval Islamic medicine is also important because of its influence on Europe, where it formed the roots from which modern Western medicine arose."}

Forcada's study from Spain offers a full and careful historical study of the practice.

The medical tradition that developed in the lands of Islam during the medieval period has, like few others, influenced the fates and fortunes of countless human beings. It is the story of contact and cultural exchange across countries and creeds, affecting caliphs, kings, courtiers, courtesans, and the common crowd. In addition to being fascinating in its own right, medieval Islamic medicine is also important because of its influence on Europe, where it formed the roots from which modern Western medicine arose. The earlier Graeco-Roman scholarly medical literature was the stem from 
which much Islamic medicine grew, just as, several centuries later, Islamic medicine was to be the core of late medieval and early European medical education. As will be seen in the following, Islamic medicine was a venue for innovation and change.

Depending on the country and climate, some recommended that the infants should be washed, as soon as they are born, with fenugreek water and barley flour; others suggested that to the salt should be added myrtle, rose, laurel leaves, pistachio tree leaves, costus or malabathron, either separately or mixed one another. It was necessary to employ these samples according to the temperaments of the countries which are hot, it may be cold regarding the infant's temperament, and that those which are cold, it may be hot regarding the infant's temperament. He who thinks that only salt suffices for achieving a balanced temperament will think that salt is enough. As for what is mixed in the water with which the infant is bathed, one must follow the very same method. The method of adding what the physicians think best is according to a particular climate, as well as the oral tradition of midwives and old women that carried forth these methods. For this reason, the country must have its own method and custom whose inhabitants follow. All this suggests a fairly consistent picture of a widely dispersed practice which is ill-understood, yet which persists in any case.

During the middle of the $12^{\text {th }}$ century, Spain's Ibn Zuhr was the only voice raised against the application of salt on newborns,

"The infant's body is like fresh cheese because his members have soft bones and. The midwife must correct what needs to be corrected with extreme care and patience. If she bathes the child, she must do so with lukewarm and sweet water, as long as he resists and avoiding that the air should damage his body."

Ibn Zuhr's opinion was that salt burns them and possibly makes them sleepless when they cannot endure the pain, and insomnia makes them weak. He says:

"I think that salt is not convenient for his body, and it seems that there areother things for the same purpose better than salt, such as acorn oil. This has the same effect of hardening, but it neither burns nor causes insomnia."

This innovation of change stems not from a systematic empirical search, nor an a priori rereading of Greek sources along Aristotelian lines. It is a simple amendment suggested either by experience, common sense, and deduction or by all these factors conjointly, just like many other criticisms and innovations which frequently appear in Arabo-Islamic medical sources. Since Galen's recommendation indicated that one should administer astringent and cleansing substances to the newborn's skin, Ibn Zuhr might have thought that acorn oil was preferable because it does not irritate. Also, other astringents were used, such as henna. Because of this, an ointment with acorn oil became a regular feature of treatises on Obstetrics and Newborn Care written leading to the Renaissance of Spain and Europe.

Different methods of salting are still used in today's Turkey as well as other parts of the world such as the Middle East, India, China. This practice is performed with the assumption that it would (a) avoid the bad smell of the body sweat from the newborn, (b) decrease sweating, (c) strengthen the muscles and bones, (d) prevent infections, and (e) ensure that injuries would heal fast. Also, it is believed to deter supernatural beings and evils; salt is tradi- tionally used with the assumption that it would not bring disease and death. Skincare practices during the immediate neonatal period and in infancy can affect the maturation and function of the epidermal barrier.

\section{"Some studies have revealed in the literature that an extensive amount of salt may cause absorption of sodium through the skin and thus epidermolysis and hypernatremia, which is a life- threatening disease with symptoms of dry or burnt-like skin.}

Some studies have revealed in the literature that an extensive amount of salt may cause absorption of sodium through the skin and thus epidermolysis and hypernatremia, which is a life-threatening disease with symptoms of dry or burnt-like skin. In many cases of salting in which the newborn babies were brought to hospitals, it has been observed that numerous medically dangerous conditions such as hypernatremia, renal failure as a complication of hypernatremia, dehydration, neonatal convulsion, skin lesions, hyperbilirubinemia, intracranial bleeding, and even death can occur. Gangrene cases have also been observed among newborn babies due to salting. Even though the salting practice in not common in the United States and urban areas of developed countries, the Emergency Room Department and Urgent Care Centers should be aware of salting practice and its results while in their evaluation of the newborn.

The normal anatomy of the skin consists of a complex of a multifunctional organ that interfaces with the organism and the environment.

Forming from the embryonic ectoderm, the epidermis contains appendages of hair follicles, sweat glands, and sebaceous glands. The main bulk-forming the dermis is derived from the embryonic mesoderm and consists of collagen embedded in a hydrated matrix of glycosaminoglycans. In addition, the epidermis is composed of multiple cell types.

1. The stratum basale, is for keratinocyte proliferation and epidermal renewal.

2. The stratum spinosum consists of tightly packed keratinocytes linked by desmosomal connections.

3. The stratum granulosum is responsible for barrier lipid synthesis and corneocyte production by programed cell death.

4. The anucleated outermost layer, the stratum corneum, which forms the interface with the environment is lacking or diminished in the Very Low Birthweight Newborn.

Research supports the hypothesis that vernix caseosa (a product of sebaceous secretions) participates in regionally "waterproofing" the skin surface.

After birth, the skin must immediately perform multiple functions vital to the survival of the organism.

The functions include the production of sweat, which is important 
for thermoregulation and bacterial homeostasis. And the acid mantle is important for production of a natural moisturizing factor, as well as hydrolysis of triglycerides and lactate generation.

It is important to understand the "barrier function of skin" which mainly resides within the stratum corneum layer of the epidermis. It consists of the keratinocytes (constituted by proteins and lipids) embedded in a lipid rich matrix, consisting of cholesterol, ceramides and fatty acids. Another class of lipids also, is secreted at the surface of the epidermis which when in contact with the environment, interacts with water forming a hydrophilic film which is important for maintaining the moisture content and sensorial attributes of the skin. The lipid fraction of this hydrophilic film canal penetrates in the upper layer of the epidermis merging with the epidermal barrier and also contributing to its functions. This is extremely important when considering what cleanser to apply on the newborn skin. Another important developmental variation of the infant skin is the "acid mantle" or the functional capacity of the skin to form a surface $\mathrm{pH}$ of less than 5 . There is close association between the skin surface $\mathrm{pH}$ and its microbial flora, because an increased skin $\mathrm{pH}$ from acidic to neutral can cause a transient increase in the total number of skin bacteria and a shift in the species present. Therefore, it is important to maintain this acid mantle on the baby's skin.

Today the Association of Women's Health, Obstetric and Neonatal Nurses and the National Association of Neonatal Nurses (AWHONN/NANN) have evaluated the skin condition of the newborn based on the dryness, erythema, and skin breakdown. Those newborns who did present with these findings did benefit in each three (3) conditions from guideline-based therapy, such as emollients. As the skin of the newborn is susceptible and sensitive to trauma and infection and requires special care, all soaps, cleansers, powder and synthetics, should be used with proper indications and cautious judgement with evidence-based recommendations for the care of newborn skin that should be integrated into the routine practice.

\section{References:}

1. Tempkin O. (translated) in: Soranus' Gynecology. Baltimore: The John Hopkins Press, 1956, pp. 83-84.

2. Al-Rāzī, Kitab Al-Mansóūrī fīl-Tibb, ed. CHasan al-Bakrī al-. iddiqī (Kuwayt: Manshūrāt Ma'had al-Makh'oo'āt al-'Arabiyya, 1987), 231-232.

3. Islamic Medicine Volume 42 'Ali Ibn Al-'Abbaas Al-Majusi (10 $10^{\text {th }}$ century) Kaamil As-Sinaa'ah At-Tibbiyyah (The Complete Art of Medicine) Book II Edited by Fuat Sezgin 1996 Institute for the History of Arabic-Islamic Science at the Johann Wolfgang Goethe University Frankfurt am Main

4. The Canon of Medicine (Al-Qaanoon fi'l Tibb) Avicenna Adapted by Laleh Bakhtiar from translations by O. Cameron Gruner and Mazar Shah 1999 Great Books of the Islamic World, Inc. pp. 359-60.

5. Salting Babies. Innovation and Tradition in Premodern Procedures for Neonatal Care Miquel Forcada The present paper is a part of a wider project funded by the Spanish Ministry of Science, 'La evolución de la ciencia en la sociedad de alAndalus desde la Alta Edad Media al pre-Renacimiento y su repercusión en las culturas europeas y árabes (siglos $X-X V$ )' ('The evolution of science in al-Andalus society since the High Middle Ages to the pre-Renaissance and its repercussion on cultures European and Arab (X-XV centuries)') ref. FFI 2008-
00234 Filo, and FFI2011-30092-C02-01.

6. E. García Sánchez, Ibn Zuhr, Abd al-Malik b. Abi l-Ala'. Kitāb al-AgÇiya/ Tratado de los alimentos (CSIC et al.: Madrid, 1992), introd., 15-16.

7. Traditional Practices Adopted by Jordanian Mothers When Caring for Their Infants in Rural Areas. Ahmad Yahya AlSagarat and Amani Al-Kharabsheh Abuidhail J. Rural Jordanian Mothers Beliefs, Knowledge and Practices of Postnatal Care. Quality in Primary Care. 2014; 222:85-293.

8. Midwifery (2009) 25, 62-71 Traditional postpartum practices of women and infantsand the factors influencing such practices in South Eastern Turkey Emine Geckil, Ph.D, your"rkan Sahin, Emel Ege, Ph.D.

9. Lawrence Conrad, 'The Arab-Islamic Medical Tradition.' In: Lawrence I. Conrad et al. (eds.), The Western Medical Tradition, 800 B.C. to $A D$ 1800. London: Cambridge University Press, 1995, pp. 93-138.

10. Development of the Epidermal Barrier Steven $B$. Hoath and Vivek Narendran NeoReviews December 2001, 2 (12) e269-e281

11. Indian Journal of Traditional Knowledge Vol. 13 (3), July 2014, pp. 445-452

12. Traditional practices frequently used for the newborn in Turkey: A literature review Nurcan Özyazıcıoğlu \& Sevinc, Polat

13. Skin Care for the Newborn Indian Pediatrics Volume 47 July 17, 2010, pp 593-98. Sarkar R, Basu S, Agrawal RK, Gupta P

14. Pediatric Annals Newborn Skin Care Yasser Albahrani, MD; Raegan Hunt, MD, PhD 2019;48(1): e11-e15

15. JOGNN Volume 41 January/February 2001 pp. 41-51 Clinical Studies Neonatal Skin Care: Clinical Outcomes of the AWHONN/NANN Evidence-Bused Clinical Practice Guideline Carolyn $H$. Lund, RN, MS, FAAN, Jason W. Osborne, PhD, Joanne Kuller, RN, MS, Alfred T. Lane, MD, FAAP, Judy Wright Lott, RNC, DNS, NNP, Deborah A. Raines, PhD, RNC

The author has no conflicts to disclose

NT



